\title{
Relationship between Postharvest Diseases Resistance and Mineral Composition of Citrus Fruit
}

\author{
C. Nunes, A. Duarte and T. Manso \\ CDCTPV, Universidade do Algarve \\ Gambelas, Ed. 8, 8005-139 Faro \\ Portugal
}

J.M. García, J.A. Cayuela, K. Yousfi and

M.C. Martínez

Instituto de la Grasa (CSIC), Sevilla

Spain

\author{
C. Weiland \\ Universidad de Huelva \\ La Rábida Huelva \\ Spain \\ M. Salazar \\ Instituto Universitário D. Alfonso III \\ Loulé \\ Portugal
}

Keywords: nutrients, Penicillium decay, postharvest decay, production systems

\begin{abstract}
Green and blue moulds, due to the pathogenic action of Penicillium digitatum and Penicillium italicum respectively are the main cause of orange losses during postharvest. Under Mediterranean climate conditions, both together are responsible for $80 \%$ of total postharvest citrus fruit decay. The type of orchard production system, field location with different types of climate and soil has a main influence on mineral composition of fruits. The mineral composition of fruits can have a significant impact on fruit quality and shelf life during postharvest period. These include effects on fruit colour, texture, disease susceptibility, juice composition and development of physiological disorders. Oranges from different regions from South of Spain and Portugal and from three different production systems (conventional, integrated and organic) were studied to evaluate whether both factors (origin and production system) affected the degree of fruit sensitivity to decay. Results indicate that the sensitivity to green or blue mould is determined better by the origin of fruit than by the system of production.
\end{abstract}

\section{INTRODUCTION}

Penicillium italicum and Penicillium digitatum are the most common postharvest pathogens of citrus fruits. $P$. digitatum works by producing ethylene to accelerate ripening. It covers the fruit with green conidia, causing the fruit to shrivel and dry out. $P$. italicum causes slimy rot and produces blue-green conidia. This species likes cooler temperatures, which explains why they are usually found on foods left too long in the refrigerator. Both diseases resemble each other in colour characteristics, style of decay, and infection symptoms; they fall under a general category called green and blue mould, when caused by $P$. digitatum and $P$. italicum respectively. These fungi live a long time and are quite durable, including even stable adverse conditions. Sometimes, fruits infected by $P$. italicum will adhere to each other to create synnemata. Penicillium growth typically occurs as a result of wound infections in produce. To prevent the development of these pathogens and to limit losses in commercial fruit shipments, treatment with chemical fungicides is a widely used procedure. However, such treatment may produce serious problems, with residues on the fruit (Cabras et al., 1999; Palou et al., 2008), appearance of fungicide-resistant strains of $P$. digitatum (Ben-Yehoshua et al., 1994), and their possible accumulation in human adipose tissue constituting an additional health threat (Suwalsky et al., 1999). As alternative to these fungicides some treatments have obtained successful results controlling postharvest decay. Thus, curing (holding fruits at relatively high temperature and humidity for 24 to $72 \mathrm{~h}$ ), dipping fruit in $\mathrm{CO}_{3} \mathrm{HNa}$, solutions at 40 to $50^{\circ} \mathrm{C}$ for 1 to $3 \mathrm{~min}$ or the use of antagonist microorganisms have been demonstrated to be a very effective alternative treatments to avoid Penicillium spp. proliferation on citrus fruit (Nunes et al., 2007; Torres et al., 2007; Pérez et al., 2008a).

However, these non-contaminant systems habitually exhibit a poorer 
reproducibility than fungicides (Palou et al., 2008). Recently, Pérez et al. (2008b) observed that fruit obtained from integrated or organic production exhibited a significant higher sensibility to Penicillium infection than the conventional ones. It means that the reduction or elimination of chemical synthesis compounds in the citrus production would cause a significant increase in sensitivity of fruits towards Penicillium. It is well known than the principal factor that impacts the preservation of harvested commodities is the physiological status of the tissue and its susceptibility to pathogen attack increases due to weakened natural defences mechanisms, as well as partial degradation of cell walls and subsequent increase leakage of solutes (Droby et al., 2001). Also some studies have looked at the possible role that phenolic compounds might play as phytoalexins in some Citrus species (Ortuño et al., 1997; Del Río, 1998; Arcas et al., 2000; Del Río et al., 2004). The level of presence of these compounds should be determinant for the progress of fungal infection and for the efficiency of the alternative system to control it. However, the reason why this presence differs with seasons and locations has not been yet explained. In this paper a possible relationship between chemical peel components $(\mathrm{N}, \mathrm{P}$, $\mathrm{K}, \mathrm{Ca}, \mathrm{Mg}, \mathrm{Fe}, \mathrm{Cu}, \mathrm{Zn}, \mathrm{Mn}$ ) of citrus fruit obtained by different production systems from different origin and the level of sensibility to $P$. digitatum and P. italicum infection has been studied to explain this variability.

\section{MATERIAL AND METHODS}

\section{Plant Material}

Oranges (Citrus sinensis 'Valencia Late') were harvest randomly from conventional, integrated and organic production systems and different regions of Southwest of Spain (Lepe - seaside of Huelva - and Río Tinto - range of Huelva) and South of Portugal (Silves - west Algarve - and Tavira - east Algarve) and were harvested in the beginning of May, June and July.

\section{Fungal Inoculation and Fruit Decay Incidence Evaluation}

$P$. digitatum and $P$. italicum isolated from decayed oranges from 3 locations (Lepe, Rio Tinto and South of Portugal) and maintained on potato dextrose agar medium (PDA), periodically transfer to fruit. Conidia of a 7-12 days culture grown at $25^{\circ} \mathrm{C}$ were suspended in sterile distilled water with Tween 80 . The suspension was adjusted to $10^{6}$ conidia $/ \mathrm{ml}$ using a haemacitometer. Oranges in sets of 4 replicates of 60 fruits from each origin and each production system were dipped in the suspensions of $P$. digitatum or $P$. italicum for $30 \mathrm{~s}$. Decay incidence of each treatment was monitored after 15 days of storage at $20^{\circ} \mathrm{C}$ and $80 \% \mathrm{RH}$.

\section{Quality Studies}

At harvest moment, fruit firmness was evaluated using 20 non-inoculated fruits from each treatment with a Zwick 3300 non-destructive hand densimeter. Subsequently fruits were distributed in 4 groups of 5 oranges, which were separately extracted to determine the percentage of juice and the percentage of peel in front of the total fresh weight of each group of fruits. The soluble solids concentration (SSC) with a refractometer and the titratable acidity with an automatic titrator that measured the volume of $0.1 \mathrm{~N} \mathrm{NaOH}$ required by $10 \mathrm{ml}$ of juice to reach $\mathrm{pH} 8.0$ were also measured. Data were expressed as ${ }^{\circ}$ Brix and percentage of citric acid, respectively. Maturity index (MI) was evaluated by the ratio: ${ }^{\circ}$ Brix / \% Citric acid for each extracted juice.

\section{Mineral Composition}

Peel of nine fruits, distributed in three groups of three fruits were dried at $60^{\circ} \mathrm{C}$ for $48 \mathrm{~h}$, grounded, ashed at $450^{\circ} \mathrm{C}$, and digested in $10 \mathrm{~cm}^{3} \mathrm{HCl} 1 \mathrm{~N}$. Standardized procedures (AOAC, 1990) were used to measure nutrient concentrations. Nitrogen was analysed by the Kjeldahl method, $\mathrm{P}$ was determined colorimetrically by the molybdo-vanadate method, $\mathrm{K}$ was measured by flame photometry, and $\mathrm{Mg}, \mathrm{Ca}, \mathrm{Fe}, \mathrm{Cu}, \mathrm{Mn}$ and $\mathrm{Zn}$ were 
measured by atomic absorption spectrometry.

\section{Statistical Analysis}

In all the parameter studied the results presented correspond to the mean values obtained in the three different harvesting dates tested. A 2-way analysis of variance (ANOVA) procedure was used for testing the possible significant effect $(P \leq 0.05)$ of the origin and the production system of the samples on the global decay incidence, independently for each fungi inoculation. A 1-way analysis of variance (ANOVA) procedure was used for testing possible significant effect $(P \leq 0.05)$ of the different combinations of origins and production systems on mineral contents and quality parameters. When the effect of the treatment was significant, means were analysed by the Tukey's HSD test $(P \leq 0.05)$. The performed data was statistically analysed using CoStat $5.01^{\mathrm{TM}}$ statistical software (Cohort Software Minneapolis, MN, USA).

\section{RESULTS AND DISCUSSION}

Results of fruit quality are shown in Table 1, decay incidence in Table 2 and mineral composition in Table 3. Globally considered, no significant effect on Penicillium decay was found as consequence of the different production systems tested (Table 2). However, conventional fruits cultured in Lepe showed a significant lower sensibility to both fungi than the oranges obtained by integrated production in the same culture location. In opposite, Silves oranges cultured under organic production exhibited significant lower incidence of $P$. digitatum decay than the fruits of the same origin produced under the other two systems. On the other hand, independently of the production system how they were cultured, Lepe oranges showed lower mean values of decay incidence than the fruits of other locations. In consequence, results seem to indicate that the sensitivity to green or blue mould is determined better by the origin of fruit than by the system of production. It is possible to conclude that the reduction or elimination of chemical synthesis compounds in the citrus production does not cause a significant increase in sensitivity of fruits towards Penicillium. It seems that the higher resistance to the pathogen could be bound more to the edafoclimatic factors of a certain culture area that to the provision type that is applied externally to it.

Although to identify clearly a determined element, whose presence or absence was coincident with higher or lower decay incidences, is not possible. Lepe oranges showed the highest mean values of $\mathrm{N}, \mathrm{Mg}$ and $\mathrm{Fe}$ and the lowest of $\mathrm{Co}$ and $\mathrm{Mn}$ (Table 3). Furthermore, Lepe oranges obtained by conventional production exhibited higher values of $\mathrm{N}$ and $\mathrm{Fe}$ than the integrated ones, but these differences did not reach a statistical significance. The higher presence of $\mathrm{N}$ and $\mathrm{Fe}$ could be directly related with a higher presence of proteins associated to $\mathrm{Fe}$ in the peel fruit. For instance, lipoxigenase is a $\mathrm{Fe}$ protein associated to natural plant defence-related compounds biosynthesis, such as hexanal $\left(\mathrm{C}_{6} \mathrm{H}_{12} \mathrm{O}\right.$ hexyl aldehyde $)$ and it is induced by cell wall breaking in plant tissues (Royo et al., 1996). At the other hand, a higher presence of $\mathrm{Mg}$ suggests higher chlorophyll content in the fruit peel and, in consequence, a lower level of fruit maturity and a higher resistance to fungal infection.

The significant lower MI values showed by Lepe oranges explained both the higher resistance to decay due to Penicillium and the higher $\mathrm{Mg}$ content in comparison to the mean values exhibited by Silves and Tavira oranges (Table 1). However, Río Tinto fruits in spite of showing similar MI values to Lepe oranges exhibited a higher sensibility to fungal infection. This fact indicates that Rio Tinto oranges are especially sensible to Penicillium attack, since they showed similar levels of decay incidence than the riper oranges produced in Portugal. In a previous work, Nunes et al. (2007) after a treatment of curing during $18 \mathrm{~h}$ at $40^{\circ} \mathrm{V}$ observed that artificially inoculated with $P$. digitatum and $P$. italicum Valencia fruit of this origin presented about 5\% of decay incidence, whereas similar treated fruits cultured in Tarragona (northwest Spain) or Tavira did not exhibit any decay. As Río Tinto oranges are characterised for exhibiting the highest contents of Mn (Table 3), results suggest that a special attention should be dedicated to the presence of 
this element in the orange peel, because it may be a limiting factor required for Penicillium infection. It is well known that numerous enzymes are Mn-dependant, especially a lot of them related with nucleotide biosynthesis and replication.

\section{ACKNOWLEDGEMENTS}

Interreg IIIA of the European Community: Project Citrisaude (SP5.P120/03).

\section{Literature Cited}

AOAC 1990. Methods of Analysis (15th ed.). Association of Official Analytical Chemist, Washington, D.C.

Arcas, M.C., Botía, J.M., Ortuño, A. and Del Río, J.A. 2000. UV Irradiation alters the levels of flavonoids involved in the defence mechanisms of Citrus aurantium fruits against Penicillium digitatum. Eur. J. Plant Pathol. 106:617-622.

Ben-Yehoshua, S, Goldschmidt, E.E. and Bar-Joseph, M. 1994. Citrus fruits. p.357-378. In: Encyclopedia of Agricultural Science Vol. 1, Academic Press, Inc., New York.

Cabras, P., Schirra, M., Pirisi, F.M., Garau, V.L. and Angioni, A. 1999. Factors affecting imazalil and thiabendazole uptake and persistence in Citrus fruits following dip treatments. J. Agr. Food Chem. 47:3352-3354.

Del Río, A., Arcas, M.C., Benavente-García, O. and Ortuño, A. 1988. Citrus polymethoxylated flavones can confer resistance against Phytophthora citrophthora, Penicillium digitatum and Geotrichum species. J. Agr. Food Chem. 46:4423-4428.

Del Río, J.A., Gómez, P., Báidez, G.A., Arcas, M.C., Botía, J.M. and Ortuño, A. 2004. Changes in the level of polymethoxyflavones and flavones as part of the defence mechanism of Citrus sinensis (cv. Valencia late) fruits against Phytophthora citrophthora. J. Agr. Food Chem. 52:1913-1917.

Droby, S., Wilson, C.L., Wisniewski, M. and El-Ghaouth, A. 2001. Biologically based technology for the control of postharvest diseases of fruits and vegetables. p.187-205. In: C. Wilson and S. Droby (eds.), Microbial food contamination. CRC Press, Boca Raton.

Nunes, C., Usall, J., Manso, T., Torres, R., Olmo, M. and García, J.M. 2007. Effect of high temperature treatments on growth of Penicillium spp. and their development on 'Valencia' oranges. Food. Sci. Tech. Int. 13:63-68.

Palou, L., Smilanick, J. and Droby, S. 2008. Alternatives to conventional fungicides for the control of citrus postharvest green and blue molds. Stewart Postharvest Review 2:2-16.

Pérez, E., Weiland, C.M., García, J.M., Domínguez, A., Bastida, F., Menéndez, J., Manso, T. and Nunes, C. 2008a. Tratamientos post-cosecha para controlar Penicillium sp. en frutos de cítricos. $2^{\circ}$ C. Nacional de Citricultura. 24-26 June. Faro (Portugal). p.16.

Pérez, E., Weiland, C.M., García, J.M, Domínguez, A., Bastida, F., Nieta, D., Manso, T. and Nunes, C. 2008b. Incidencia de Penicillum sp. en cítricos en post-cosecha según el modo de producción: convencional, integrada y ecológica. $2^{\circ} \mathrm{C}$. Nacional de Citricultura. 24-26 June. Faro (Portugal). p.17.

Ortuño, A., Reynaldo, I., Fuster, M.D., Botía, J.M., García-Puig, D. and Sabater, F. 1997. Citrus cultivars with high flavonoid contens in the fruits. Scientia Hort. 68:231-236.

Royo, J., Vancanneyt, G., Pérez A.G., Sanz C., Störmann, K., Rosahl, S. and SánchezSerrano, J.J. 1996. Characterization of three potato lipoxigenases with distinct enzymatic activities and different organ-specific and wound- regulated expression patterns. J. Biol. Chem. 271:21012-21019.

Suwalsky, M., Rodríguez, C., Villena, F., Aguilar, F. and Sotomayor, C.P. 1999. The pesticide hexachlorobenzene induces alterations in the human erythrocyte membrana. Pestic. Biochem. Phys. 10:205-214.

Torres, R., Nunes C., Garcia, J.M., Abadias, M., Viñas, I., Manso, T., Olmo, M. and Usall, J. 2007. Application of Pantoea agglomerans CPA-2 in combination with heated sodium bicarbonate solutions to control the major postharvest diseases affecting citrus fruit at several Mediterranean locations. Eur. J. Plant Pathol. 118:73-83. 


\section{Tables}

Table 1. Quality parameters of 'Valencia Late' oranges from different origins and production systems.

\begin{tabular}{|c|c|c|c|c|c|c|c|c|c|}
\hline $\begin{array}{l}\text { Origin and } \\
\text { Production } \\
\text { system }^{\mathrm{x}}\end{array}$ & $\begin{array}{l}\text { Weight } \\
(\mathrm{g})\end{array}$ & $\begin{array}{l}\text { Firmness } \\
(\mathrm{N})\end{array}$ & $\begin{array}{c}\text { Peel } \\
\text { (\% fruit } \\
\text { weight) }\end{array}$ & $\begin{array}{c}\text { Juice } \\
(\%)\end{array}$ & $\begin{array}{c}\text { Pulp } \\
(\%)\end{array}$ & $\mathrm{pH}$ & $\begin{array}{c}\text { Acidity } \\
(\% \\
\text { Citric }) \\
\end{array}$ & $\begin{array}{l}\text { S. solids } \\
\left({ }^{\circ} \text { Brix }\right)\end{array}$ & $\begin{array}{c}\text { Maturity } \\
\text { Index } \\
\left({ }^{\circ} \text { Brix / \% }\right. \\
\text { Citric) } \\
\end{array}$ \\
\hline Lepe & & & & & & & & & \\
\hline $\begin{array}{l}\text { Conventional } \\
\text { Lepe }\end{array}$ & 141.9ab & $20.4 b$ & $24.9 \mathrm{a}$ & $52.5 \mathrm{a}$ & 37.2 & 3.3 & $23.6 b$ & $12.7 \mathrm{c}$ & $0.54 \mathrm{a}$ \\
\hline $\begin{array}{l}\text { Integrated } \\
\text { Rio Tinto }\end{array}$ & $149.5 \mathrm{ab}$ & $20.7 b$ & $25.9 \mathrm{a}$ & $55.8 \mathrm{a}$ & 35.5 & 3.3 & $22.1 \mathrm{~b}$ & $11.9 b c$ & $0.54 \mathrm{a}$ \\
\hline $\begin{array}{l}\text { Integrated } \\
\text { Rio Tinto }\end{array}$ & $129.0 \mathrm{a}$ & $18.5 \mathrm{a}$ & $24.4 \mathrm{~b}$ & $57.8 \mathrm{a}$ & 36.7 & 3.7 & $20.7 b$ & $10.2 \mathrm{a}$ & $0.49 \mathrm{a}$ \\
\hline $\begin{array}{l}\text { Organic } \\
\text { Tavira }\end{array}$ & $177.7 \mathrm{bc}$ & $20.2 b$ & $29.1 \mathrm{a}$ & $64.7 \mathrm{a}$ & 36.5 & 4.1 & $22.6 b$ & $10.4 \mathrm{ab}$ & $0.46 a$ \\
\hline $\begin{array}{l}\text { Integrated } \\
\text { Silves }\end{array}$ & $215.1 \mathrm{~cd}$ & $19.2 \mathrm{ab}$ & $21.7 \mathrm{a}$ & $93.7 b$ & 43.6 & 3.5 & $10.1 \mathrm{a}$ & $12.0 \mathrm{c}$ & $1.19 b$ \\
\hline $\begin{array}{l}\text { Conventional } \\
\text { Silves }\end{array}$ & $132.9 \mathrm{a}$ & $20.4 b$ & $26.1 \mathrm{a}$ & $57.2 \mathrm{a}$ & 39.2 & 3.6 & $12.0 \mathrm{a}$ & $12.8 \mathrm{c}$ & $1.07 \mathrm{~b}$ \\
\hline Integrated & $239.9 d$ & $20.3 b$ & $24.3 \mathrm{a}$ & $88.6 \mathrm{~b}$ & 36.6 & 3.6 & $9.6 \mathrm{a}$ & $11.7 \mathrm{bc}$ & $1.22 \mathrm{~b}$ \\
\hline
\end{tabular}

Table 2. Decay incidence decay of 'Valencia Late' oranges from different origins and production systems.

\begin{tabular}{|c|c|c|c|c|c|c|c|c|}
\hline \multirow{2}{*}{$\begin{array}{l}\text { Decay } \\
\text { Incidence } \\
(\%) \\
\text { Sample }\end{array}$} & \multicolumn{8}{|c|}{$\begin{array}{c}\text { Production system } \\
\text { Species of Penicillium inoculated }\end{array}$} \\
\hline & \multicolumn{2}{|c|}{ Conventional } & \multicolumn{2}{|c|}{ Integrated } & \multicolumn{2}{|c|}{ Organic } & \multicolumn{2}{|c|}{ Average } \\
\hline origin & P. dig. & P. ital. & P. dig. & P. ital. & P. dig. & P. ital. & P. dig. & P. ital. \\
\hline Lepe & $82.1 \mathrm{bB}$ & $82.1 \mathrm{bB}$ & $95.7 \mathrm{aB}$ & $87.1 \mathrm{aB}$ & - & - & $88.9 \mathrm{~B}$ & $84.6 \mathrm{~B}$ \\
\hline Río Tinto & - & - & $98.5 \mathrm{AB}$ & $97.0 \mathrm{~A}$ & $100.0 \mathrm{~A}$ & 98.5 & $99.2 \mathrm{~A}$ & $97.8 \mathrm{~A}$ \\
\hline Tavira & $100.0 \mathrm{~A}$ & $97.1 \mathrm{~A}$ & - & - & - & - & $100 \mathrm{~A}$ & $97.1 \mathrm{~A}$ \\
\hline Silves & $98.5 \mathrm{aA}$ & $100.0 \mathrm{~A}$ & $100.0 \mathrm{aA}$ & $100 \mathrm{~A}$ & $95.6 \mathrm{bB}$ & 97.0 & $98.0 \mathrm{~A}$ & $99.0 \mathrm{~A}$ \\
\hline Average & 93.5 & 93.1 & 96.3 & 93.7 & 97.8 & 97,8 & 95.7 & 94.4 \\
\hline
\end{tabular}


Table 3. Mineral composition of Valencia Late oranges from different origins and production systems.

\begin{tabular}{|c|c|c|c|c|c|c|c|c|c|c|}
\hline \multirow[b]{2}{*}{$\begin{array}{l}\text { Sample } \\
\text { origin }\end{array}$} & \multirow[b]{2}{*}{$\begin{array}{l}\text { Production } \\
\text { system }\end{array}$} & \multicolumn{9}{|c|}{$\begin{array}{l}\text { Mineral composition }^{\mathrm{z}} \\
\text { Macronutrients }\left(\mathrm{g} \mathrm{kg}^{-1}\right)^{\mathrm{y}} \text { and Micronutrients }\left(\mathrm{mg} \mathrm{kg}^{-1}\right)^{\mathrm{y}}\end{array}$} \\
\hline & & $\mathrm{N}$ & $\mathrm{P}$ & $\mathrm{K}$ & $\mathrm{Ca}$ & $\mathrm{Mg}$ & $\mathrm{Fe}$ & $\mathrm{Co}$ & $\mathrm{Zn}$ & $\mathrm{Mn}$ \\
\hline \multirow[t]{2}{*}{ Lepe } & Conventional & 11.5 & 0.8 & 6.1 & 4.8 & 1.4 & 8.3 & 4.0 & 6.0 & 7.0 \\
\hline & & $\mathrm{b}$ & $\mathrm{ab}$ & $\mathrm{a}$ & $\mathrm{ab}$ & $\mathrm{b}$ & $\mathrm{b}$ & $\mathrm{b}$ & $\mathrm{ab}$ & $\mathrm{b}$ \\
\hline \multirow[t]{2}{*}{ Lepe } & Integrated & 10.2 & 0.7 & 5.4 & 6.8 & 1.5 & 7.5 & 5.0 & 6.0 & 7.0 \\
\hline & & $a b$ & $\mathrm{a}$ & $\mathrm{a}$ & bc & $\mathrm{b}$ & $\mathrm{ab}$ & $\mathrm{b}$ & $\mathrm{ab}$ & $\mathrm{b}$ \\
\hline \multirow[t]{2}{*}{ Río Tinto } & Integrated & 9.6 & 0.9 & 9.0 & 5.1 & 1.2 & 7.3 & 8.0 & 8.0 & 12.0 \\
\hline & & $a b$ & $\mathrm{c}$ & b & $\mathrm{ab}$ & $a b$ & $\mathrm{ab}$ & b & $\mathrm{b}$ & $\mathrm{a}$ \\
\hline \multirow[t]{2}{*}{ Río Tinto } & Organic & 10.5 & 1.0 & 9.0 & 4.4 & 1.2 & 7.2 & 8.0 & 6.0 & 14.0 \\
\hline & & $a b$ & $\mathrm{c}$ & b & $\mathrm{a}$ & $a b$ & $\mathrm{ab}$ & b & $\mathrm{ab}$ & $\mathrm{a}$ \\
\hline \multirow[t]{2}{*}{ Tavira } & Conventional & 10.7 & 0.9 & 7.1 & 6.7 & 0.9 & 6.6 & 13.0 & 7.0 & $9.0 \mathrm{~b}$ \\
\hline & & $a b$ & $a b$ & $\mathrm{ab}$ & bc & $\mathrm{a}$ & $\mathrm{ab}$ & $\mathrm{a}$ & $\mathrm{ab}$ & \\
\hline \multirow[t]{2}{*}{ Silves } & Conventional & 9.9 & 0.8 & 5.4 & 8.7 & 0.8 & 6.0 & 7.0 & 4.0 & $7.0 \mathrm{~b}$ \\
\hline & & $a b$ & $\mathrm{ab}$ & $\mathrm{a}$ & $\mathrm{cd}$ & $\mathrm{a}$ & $\mathrm{a}$ & b & $\mathrm{a}$ & \\
\hline \multirow[t]{2}{*}{ Silves } & Integrated & 9.1 & 0.8 & 5.0 & 9.2 & 1.2 & 6.7 & 6.0 & 4.0 & $8.0 \mathrm{~b}$ \\
\hline & & $\mathrm{a}$ & $\mathrm{ab}$ & $\mathrm{a}$ & d & $a b$ & $\mathrm{ab}$ & $\mathrm{b}$ & $\mathrm{a}$ & \\
\hline
\end{tabular}

${ }^{\mathrm{z}}$ Means of the 3 harvest dates. Within each column the same lower case letter indicate no significant difference due to origin and production system according to Tukey's HSD test $(P \leq 0.05)$.

${ }^{\mathrm{y}}$ Dry weight 